\title{
Exploration of Improving Students' Ability to Use English by the Application of English Literature
}

\author{
Hongyan Guan
}

Xi'an University, Xi'an Shaanxi, 710065, China

Keywords: English literature, Teaching, Application ability.

\begin{abstract}
College English teaching places great emphasis on building students' ability of application. In accordance with the requirements of English teaching reform in colleges and universities, following the rules of English teaching and the needs of learners' own emotions, improving students' English proficiency by English literature teaching should be used as an important goal. It is necessary to make full use of college English literature teaching and constantly improve learners' ability to use English so as to cultivate highly qualified personnel with good English practical ability. This paper analyzes the current situation of English literature teaching in China, expounds the urgency and principle of improving students' English ability in college English literature teaching and puts forward some countermeasures to improve students' English ability in English literature teaching.
\end{abstract}

\section{Introduction}

In the current college English teaching systems in China, English literature teaching is of great importance for enhancing learners' English proficiency. Although a large number of scholars have carried out quite a lot of researches on English literature teaching and have continued to increase the important content of literature teaching in the process of teaching, focusing on enhancing the cross-cultural awareness of learners, most of the colleges and universities have done a lot of work in English literature teaching The significance, role and purpose of understanding are still rather shallow, especially in the theory of English literature teaching is not sound enough. Therefore, a comprehensive study should be carried out on the functions and principles of literary education in English teaching at colleges and universities. In addition, students' ability to use English in English teaching should be enhanced.

\section{Analysis of Current Situation of English Literature Teaching in China}

In recent years, English teaching in our country has obtained great achievements, and the English proficiency of college students has been greatly improved. Generally speaking, it is the key content of college English education in our country nowadays to cultivate the comprehensive application ability of English listening, speaking, reading, writing and translating of college students. However, we should not deny our English There are still some shortcomings in teaching for cultivating students' ability to use English. The ability of college students to use English to carry out interpersonal communication is not strong enough. Therefore, at present, the lack of ability cultivation for students in English education in our country directly affects the embodiment of their creative abilities and research abilities. The tendency of students to focus on imitation while ignoring creativity still exists. Nowadays English teaching has begun to focus on function and neglect of humanities. The undergraduates' English proficiency has been on the decline. Because of the influence of English tool theory, the utilitarian function of English has been more and more emphasized, and its humanities and innovation have been ignored, resulting in difficulties in English education reflects the humanities and aesthetics and other aspects of the role, but has become quite strong practical language education, which is certainly not standardized. 


\section{Urgency of Improving English Ability of Students in College English Literature Teaching}

In order to effectively promote the process of college English teaching reform, the Ministry of Education proposed in the teaching requirements of college English courses that the purpose of college English teaching is to cultivate the ability of college students to apply English, especially listening and speaking skills, In the process of work and interpersonal communication, we can implement fruitful verbal and written communication in English, but also enhance the ability and overall quality of self-directed learning in order to meet the needs of future economic and social development and foreign exchange. The ability of English learners to cultivate learners as mentioned here conveys the following message to college English teaching workers: The ability to care for students' listening, speaking, reading, writing, translating and other traditional English is not enough because of English ability is not limited to the above five skills. To a certain extent, a strong comprehensive language proficiency fee should be close to a certain language, including the ability to read and write, including cultural quality education. One of the most obvious features of college English that is different from other social sciences is its humanistic nature. Most of the textbooks in college English, whether in terms of choice of words, structure of sentences, and layout of texts. The use of rhythm, all have a very abundant emotion, a lot of content are human sincere show. Therefore, to cultivate learners' ability in English literature can also promote physical and mental health and enable them to achieve all-round development in both intelligence and mind and body. Therefore, in view of the reform of English teaching in colleges and universities, it is necessary to follow the rules of English teaching and the needs of students 'own emotions, guide English educators in colleges and universities to effectively change their own concepts and improve students' English proficiency in English literature teaching.

\section{Principles of Improving Students' English Application Ability in College English Literature Teaching}

English literature teaching has a very important position in the current college English teaching system. However, how to exactly use English literature teaching to improve students' English ability and humanistic accomplishment, it is worth for teachers to conduct in-depth study. In my opinion, the following three principles must be practiced in the teaching of college English literature: First, the systematic teaching principle. English teaching is a very complex and systematic education project. When implementing the teaching of content, we should not only take learners' linguistic abilities into consideration, but also pay full attention to their basic skills such as English grammar, vocabulary and culture. Therefore, in college English literature teaching must be based on systematic principles, starting from the fundamental purpose of classroom teaching, the current teaching methods to implement the corresponding improvement and innovation, focusing on individual development of students on the basis of its continuous improvement Communication, interpersonal skills and English thinking ability. Second, the principle of communicative teaching. The training of English language proficiency can only be implemented in the form of communication. Therefore, we must use this principle in college English literature teaching. In general, learners' communicative competence is mainly achieved by individuals through different forms of application to achieve their own interpersonal communication. To a large extent, this ability can demonstrate the comprehensive quality of individuals, such as basic English knowledge, English culture knowledge and cognitive ability of individual students. Third, the principle of relevance teaching. It is necessary to fully improve students' ability to use English in the teaching of English literature in colleges and universities. Therefore, we must fully understand the relationship between language and culture. No matter what language learners learn, they must develop at the same time, though different from each other, their corresponding internal relations, that is, their language ability and social ability. Therefore, the process of implementing English teaching is not just the education process of a certain language, but at the same time it is also a kind of cultural instillation process. The use of college English literature teaching can not only enable college students to acquire basic English knowledge, but also 
develop their social ability that is the ability of intercultural thinking, thus forming a broad and inclusive good mentality for all kinds of foreign cultures. In this way, Can overcome the narrow, extreme and unilateral nationalist ideas.

\section{Countermeasures of Improving Students' English Application Ability in College English Literature Teaching}

\subsection{Reform English literature teaching methods}

Although English basic knowledge and cultural knowledge teaching plays an extremely important role in English teaching in colleges and universities, teachers still must choose reasonable teaching methods to provide necessary content for learners. In the traditional sense of the process of college English teaching, English teaching is generally based on the teacher as the main body, students can only passively accept the relevant knowledge. A considerable part of English literature teachers do not pay attention to students' English language proficiency training, and some English teachers apply similar teaching methods to other courses in literary subject teaching, resulting in the lack of new ideas in college English literature teaching, change. The author believes that the reform of English literature teaching in colleges and universities focuses on the integration of the relevant questions and class questions, after-school assignments and evaluation in the classroom teaching, and introduces the method of cultural teaching to guide students to English literature. In the relevant language knowledge teaching, we must adopt personal growth mode to guide students to use the necessary memory and recitation to accumulate the corresponding knowledge of language and literature. In the meantime, when using the literature means to carry on the teaching, should also conscientiously follow the principle of literature teaching, carry on the corresponding analysis to the literary method involved in teaching. After the end of the classroom teaching, teaching evaluation should also be implemented. Teaching assessment of students' ability to apply should attach great importance to formative evaluation. In order to implement more effective supervision and evaluation on learners' autonomous learning of English literature, they should also include the assessment of the content of English language output in the context of the application of proficiency testing. At the same time, they should also appropriately include commentary on literary works, Research, review and other content ratio. In the process of evaluating students' teaching of English literature, the author can also examine the emotional characteristics so that students can fully exert their emotions and achieve new improvements in their ability to apply.

\subsection{Actively expand English literature teaching content design}

In the arrangement of college English literature teaching content, we should also take into account the factors of application ability. Based on the implementation of the curriculum system, we should systematically and scientifically select and reorganize the teaching contents so as to select English literary works with more teaching meaning and space, so as to guide students to study literary works Improve your English proficiency while conducting deeper reading. For example, the controversial space in the famous work Hamlet by Grand Slam Shakespeare is quite large. Teachers are fully available to students for interpretation and independent thinking and debate. "To be, or not to be" helps the students to deepen understanding, improve the ability of the application of important sentences. The extension of teaching contents of English literature education in colleges and universities can also be fully introduced into English and American literary classics for interpretation. It can provide a more appropriate opportunity for conducting literary criticism. When interpreting Anglo-American literary works from multiple perspectives, students should also conduct omnibearing and multi-perspective autonomous thinking and cultivate their English proficiency in college students. Students can engage in debating dialogues with other people on a certain part of English literary works. Under repeated arguments and arguments, students can continuously improve their understanding of English and further develop students' ability to think independently and solve their problems. Problem-solving skills. For example, when analyzing the famous Walden by the famous writer Thoreau, teachers can guide students to think independently and lead them to explore 
the theory of ecological criticism. The work of writer Naipaul, A Way in the World, guides students to explore the aspects of history and culture.

\subsection{Actively introduce advanced technology to assist teaching}

In view of the continuous development of modern information technology, a considerable number of colleges and universities set up specialized English phonetic laboratories, which provide teachers with the conditions for the full introduction of information technology in college English literature teaching. English teachers in the classroom design should use the application of network knowledge, and effectively join the relevant teaching content. At the same time, there are quite a few masterpieces of English literature that have been adapted into works of video and film. Teachers can play a part in teaching videos so as to enhance their students' knowledge of relevant cultural knowledge and enhance their ability in English application. Colleges and universities can also set up specialized English education system, so that students can use the system to complete the task. Of course, teachers can also use this system to track students accordingly, in order to enhance their related application capabilities.

\subsection{Comprehensive integration of English literature teaching resources}

English teachers in the implementation of English literature teaching design process, should be the first comprehensive implementation of the teaching content, continue to improve learners' ability to use English. At the same time, we should give full play to the important role of teaching, link up the knowledge of vocabulary and grammar and the content of teaching materials in English literature, and make the dynamic narration about the application of language and rhetoric in literary works. The most important way in English literature teaching is to make full use of the relevant knowledge of English culture. Therefore, during the implementation of curriculum design, teachers should effectively integrate many relevant cultural background knowledge and literary content, so as to effectively improve their English proficiency.

\subsection{Increase activities inside and outside of English class to enhance literacy}

The English classrooms in colleges and universities should effectively focus on learners, with the main objective of cultivating their autonomous learning ability. Therefore, classroom activities are an indispensable part of it. College English teachers should fully seize the opportunity to actively cultivate the literary accomplishment of college students in the process of activities and guide students to fully understand the literary nature of their works so as to extend the cultivation of students' applied abilities beyond the classroom. In fact, the activities inside and outside the class are very important in improving college students' English ability. Students can improve their English literacy and practical English ability by choosing English and American literature courses, watching English literature lectures or English original films.

\section{Conclusions}

In general, to enhance students' English proficiency has become a very urgent research topic. College English literature teaching is of extremely important value in enhancing learners' ability of applying English and developing their intercultural thinking ability. Therefore, the current teaching staff of English literature courses in institutions of higher learning should take appropriate countermeasures according to the teaching reality of the subject and the principles they need to follow, so as to greatly enhance students' ability to use English so as to further improve their comprehensive English ability and to cultivate Produce English talents with higher practical ability.

\section{References}

[1] Wang Yufeng, Chen Zhigan. On the Teaching Ideas and Methods of Anglo - American Literature Courses at College English Majors, Journal of Changchun University, 2011(11).

[2] Yang Huiyong. An Analysis of the Effective Fusion of College English and Anglo - American 
Literature in the Network Environment, Journal of Shandong Agricultural Engineering College, 2015(9).

[3] Sun Yu. The Application of Six Elements of Constructivism Learning Design in English Teaching, New education era, 2015(11).

[4] Yan Enlu. Combined with flip classroom teaching mode, English and American classical literature reading into college English teaching, Foreign Language Education and Translation Development Innovation Research, 2016(3).

[5] Yang Fali. 2016. Strategies for Improving Students' Practical Ability in College English Teaching, Western Quality Education, 2016(10). 